\section{Edited by:}

Martin G. Klotz, University of North Carolina at Charlotte, USA

Reviewed by:

Niels-Ulrik Frigaard, University of

Copenhagen, Denmark

Christiane Dahl, Rheinische

Friedrich-Wilhelms-Universität Bonn,

Germany

*Correspondence:

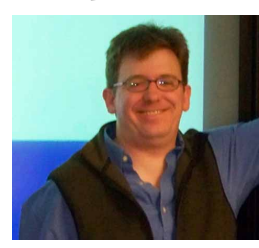

Thomas E. Hanson is a Microbiologist who specializes in the study of microbial metabolism using genetic, genomic, biochemical and chemical techniques. He also has interests in microbial ecology and biogeochemistry. Ultimately, he would like to contribute to breaking down the pure culture-real world divide. $\mathrm{He}$ sees this as the largest problem in Microbiology today. tehanson@udel.edu

\title{
Phototrophic sulfide oxidation: environmental insights and a method for kinetic analysis
}

\section{Thomas E. Hanson ${ }^{1,2,3 *}$, George W. Luther III ${ }^{1,4}$, Alyssa J. Findlay ${ }^{1}$, Daniel J. MacDonald ${ }^{4}$ and Daniel Hess ${ }^{4}$}

1 School of Marine Science and Policy, University of Delaware, Lewes, DE, USA

${ }^{2}$ Department of Biological Sciences, University of Delaware, Newark, DE, USA

${ }^{3}$ Delaware Biotechnology Institute, University of Delaware, Newark, DE, USA

${ }^{4}$ Department of Chemistry and Biochemistry, University of Delaware, Newark, DE, USA

Previously, we presented data that indicated microbial sulfide oxidation would out-compete strictly chemical, abiotic sulfide oxidation reactions under nearly all conditions relevant to extant ecosystems (Luther et al., 2011). In particular, we showed how anaerobic microbial sulfide oxidation rates were several orders of magnitude higher than even metal catalyzed aerobic sulfide oxidation processes. The fact that biotic anaerobic sulfide oxidation is kinetically superior to abiotic reactions implies that nearly all anaerobic and sulfidic environments should host microbial populations that oxidize sulfide at appreciable rates. This was likely an important biogeochemical process during long stretches of euxinia in the oceans suggested by the geologic record. In particular, phototrophic sulfide oxidation allows the utilization of carbon dioxide as the electron acceptor suggesting that this process should be particularly widespread rather than relying on the presence of other chemical oxidants. Using the Chesapeake Bay as an example, we argue that phototrophic sulfide oxidation may be more important in many environments than is currently appreciated. Finally, we present methodological considerations to assist other groups that wish to study this process.

Keywords: phototrophic bacteria, sulfide oxidation, Chesapeake Bay, voltammetry, euxinia

\section{INTRODUCTION}

The accumulation of molecular oxygen in Earth's biosphere was not instantaneous with the onset of oxygenic photosynthesis. Rather, it is thought to have occurred over billions of years and not necessarily as a smooth gradual progression of $\mathrm{O}_{2}$ concentrations, but as a series of at least two steps (Scott et al., 2008; Frei et al., 2009; Farquhar et al., 2011). Substantial reservoirs of reduced chemical species (i.e., $\mathrm{Fe}^{2+}$ and $\mathrm{HS}^{-}$) are thought to have existed in early oceans and these would have to be oxidized prior to the full oxygenation of the oceans. Furthermore, as $\mathrm{O}_{2}$ production is light dependent, ocean oxygenation and oxidation was most likely a top down process, i.e., shallow layers with highest oxygen production rates would have become oxygenated more rapidly over time than deep water layers (Figure 1). The Archaean ocean was ferruginous with low sulfur concentrations (Canfield et al., 2000). The initial rise of oxygen in the atmosphere increased continental weathering 


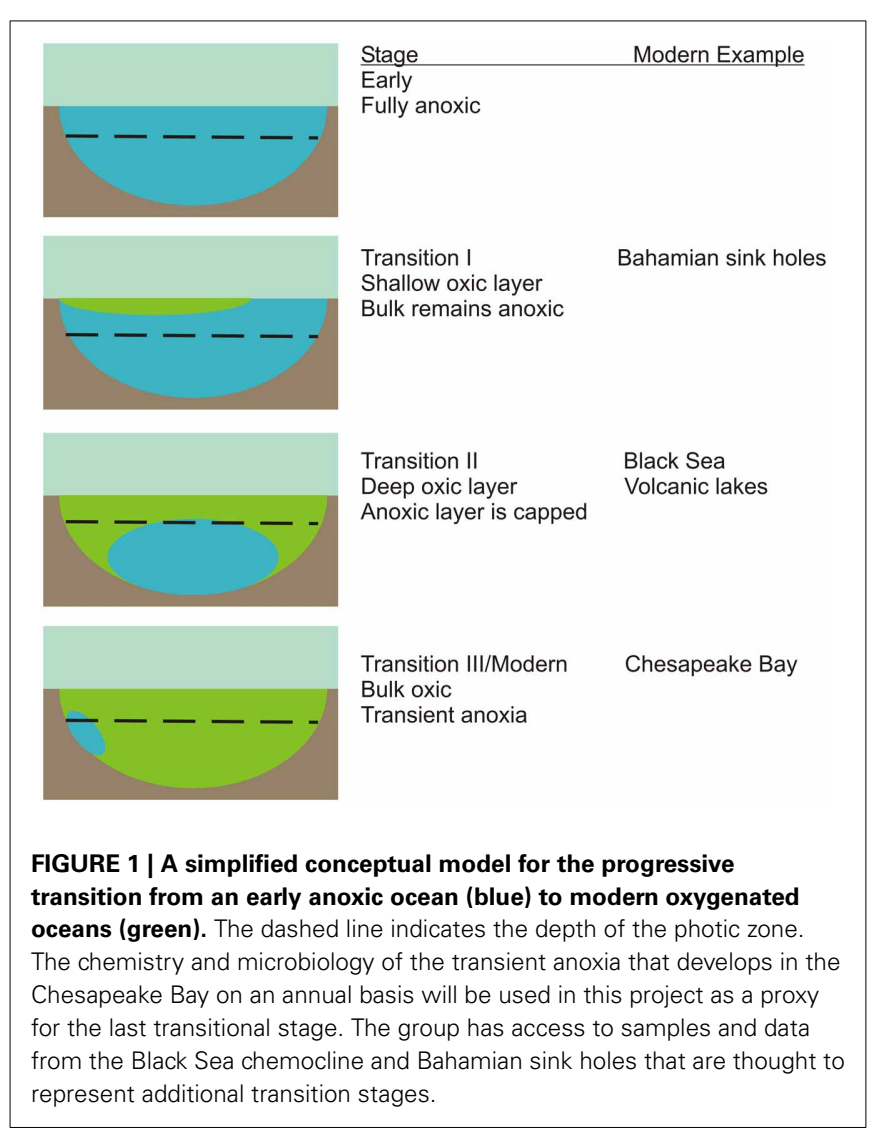

thus increasing the flux of oxidized sulfur species to the oceans (Scott et al., 2008). Evidence suggests that resulting sulfate reduction led to a sulfidic ocean being established $\sim 1.8 \mathrm{Gyr}$ ago (Poulton et al., 2004) that persisted until 0.6-0.5 Gyr ago (Wille et al., 2008; Gill et al., 2011). However, recent data indicate that ferruginous conditions also existed for at least the first half of this time period suggesting a dynamic and variable ocean during this transition.

\section{KEY CONCEPT 1 | Ferruginous}

Environments characterized by anoxia and the presence of soluble ferrous iron that produces oxides when exposed to oxic conditions.

From this reasoning, it follows that microbial sulfide oxidation in marine systems must have become important after the first flush of sulfate to the oceans and microbial sulfide oxidizers may have been major components of the pelagic marine microbial community for upwards of 1.2 billion years. Furthermore, as oxygen increased in the atmosphere and the oceans, microbial sulfide oxidizers would have experienced drastic changes to their environments that would have required adaptation or extinction. In this review, we speculate on the role of phototrophic sulfide oxidizing bacteria in modern analogs of ancient oceans using the Chesapeake Bay as an illustrative example. We also provide technical details on one method for measuring phototrophic dependent sulfide oxidation. While this is an unusual structure for a review article, we hope to both stimulate interest in the first part of the review and then equip the reader with a tool to help transform interest into practical experiments that will, hopefully, avoid pitfalls in performing and interpreting light-dependent sulfide oxidation rate measurements.

\section{OCEAN OXYGENATION AND ANCIENT OCEAN ANALOGS: A BRIEF OVERVIEW}

Just prior to the evolution of oxygenic photosynthesis, an ocean that was fully anoxic throughout its depth existed. As oxygen production rates increased, likely driven by Cyanobacteria in ocean margins, oxygen would have spread from shallows and edges. This shallow layer would eventually spread and cap off deeper water layers that remained anoxic. Over time, continued photosynthetic oxygen production would produce the essentially fully oxic oceanic water column that currently exists except for suboxic zones (defined here are as $<3 \mu \mathrm{M} \mathrm{O} 2$ and $<0.2 \mu \mathrm{M} \mathrm{H} 2 \mathrm{~S}$ as in Trouwborst et al., 2006). This model suggests there must have existed through time, several stages of transitional oceans that were partially oxic, presumably with an oxic upper layer overlying lower anoxic layers (Figure 1).

\section{KEY CONCEPT 2 | Suboxic}

Zones of very low $\mathrm{O}_{2}$ and sulfide concentration $(<3 \mu \mathrm{M}$ and $0.2 \mu \mathrm{M}$, respectively)

This dynamic and long term change in ocean redox conditions had profound consequences for marine chemistry and microbiology (Sleep and Bird, 2008). As ocean redox chemistry evolved, so did niches for marine microbes. For example, strictly anaerobic sulfide oxidizing phototrophic bacteria would have found progressively less suitable niche space as sulfide was pushed deeper in the water column and away from the photic zone by encroaching oxygen. The same would be true for $\mathrm{Fe}^{2+}$ oxidizing anoxygenic phototrophs (Crowe et al., 2008). In contrast, the increased presence of suitable oxidants (i.e., nitrate and $\mathrm{O}_{2}$ ) would have increased the available niche space for $\mathrm{Fe}^{2+}$ and $\mathrm{HS}^{-}$oxidizing chemolithoautotrophs.

There has been considerable interest in microbial communities that reside in environments considered analogous to transitional oceans. The Black Sea (Manske et al., 2005; Marschall et al., 2010) and persistently stratified volcanic lakes (Crowe et al., 2008) serve as later stage analogs for oxygen capped euxinic and ferruginous systems, respectively. In contrast, Bahamian blue holes (Steadman et al., 2007; Macalady et al., 2010; Gonzalez et al., 2012) serve as possible analogs for an earlier system with a shallower oxic layer. Here, we propose the Chesapeake Bay as an additional system that likely corresponds to very late stages of ocean oxygenation.

\section{KEY CONCEPT 3 | Euxinic}

Environments characterized by anoxia, restricted hydrologic circulation (i.e., stratification) and the presence of sulfide.

\section{THE CHESAPEAKE BAY SYSTEM}

The seasonal development of hypoxia/anoxia in the upper and middle regions of the Chesapeake Bay has been extensively documented. Low $\mathrm{O}_{2}$ conditions in the bottom waters are produced and maintained during the summer months by salinity stratification of the water column (Officer et al., 1984; Boicourt, 1992) and microbial decomposition of organic matter in the water column 
and sediments (Jonas and Tuttle, 1990; Jonas, 1992, 1997; Kemp et al., 1992) such that discrete oxic, suboxic and anoxic zones can be determined (Lewis et al., 2007). Persistent low $\mathrm{O}_{2}$ conditions in the bottom waters generally occur from May-September with the most pronounced oxygen depletion in late July and August (Taft et al., 1980; Malone, 1991). The severity of bottom-water suboxia/anoxia varies inter-annually with changes in the magnitudes of the spring freshet and nutrient inputs (Schubel and Pritchard, 1986; Malone et al., 1988; Harding et al., 1992; Hagy et al., 2004).

Superimposed on the general seasonal cycle of dissolved $\mathrm{O}_{2}$ levels are strong tidally-driven semi-diurnal oscillation, lateral seiching, and/or episodic wind-forced pycnocline disruptions (e.g., storm mixing) (Itsweire and Phillips, 1987; Breitburg, 1990; Sanford et al., 1990; Luther et al., 2004). Sanford et al. (1990), for example, collected time series measurements of dissolved oxygen (DO) and salinity at several moorings along a cross-axial transect of the mid-Bay during the summer of 1987. The strongest observed response was that due to tidal forcing. Large changes in DO and salinity at semi-diurnal and diurnal frequencies (i.e., in phase with the surface tides) were attributed to vertical movement of the pycnocline, driven by surface-forced internal tides. Longer period (sub-tidal frequency) fluctuations in DO and salinity were correlated with wind-forcing.

In addition to changes in the vertical DO profile, physical mixing processes are expected to alter the vertical distributions of other redox sensitive chemical constituents and microbial species, which depend on these chemical gradients, as well. Lewis et al. (2007) documented short-term tidal fluctuations in the depth and thickness of the suboxic layer due to tidal forcing and found episodic changes in the vertical distributions of dissolved $\mathrm{O}_{2}$, $\mathrm{Mn}^{2+}, \mathrm{Fe}^{2+}$, and $\mathrm{H}_{2} \mathrm{~S}$ in the Chesapeake Bay water column.

Compared to our understanding of the environmental chemistry in the Chesapeake Bay, there is relatively little known about the microbiology of this system and how it changes during oxic to anoxic transitions including the dynamic short-term tidally and meterologically driven changes in chemical gradients. We are aware of only one study that has directly addressed microbial community structure during anoxia in the Chesapeake Bay (Crump et al., 2007). That study utilized denaturing gradient gel electrophoresis of $16 \mathrm{~S}$ rDNA amplicons coupled to some chemical data to examine microbial communities at several depths in the summer of 2004. They concluded that microbial community doubling times were much more rapid than the duration of anoxia and demonstrated microbial community shifts during the onset of anoxia and increase in sulfide concentrations. While the Crump et al. study provided a general picture of microbial community shifts, little information was developed on the function of the community relative to sulfide: no relevant isolates were recovered, functional gene diversity related to sulfur oxidation was not addressed, nor were sulfide oxidation activity measurements carried out.

\section{LIGHT-DEPENDENT SULFIDE CONSUMPTION IN THE CHESAPEAKE BAY}

In 1988, Luther and co-workers reported water samples collected below the pycnocline in the Chesapeake Bay water

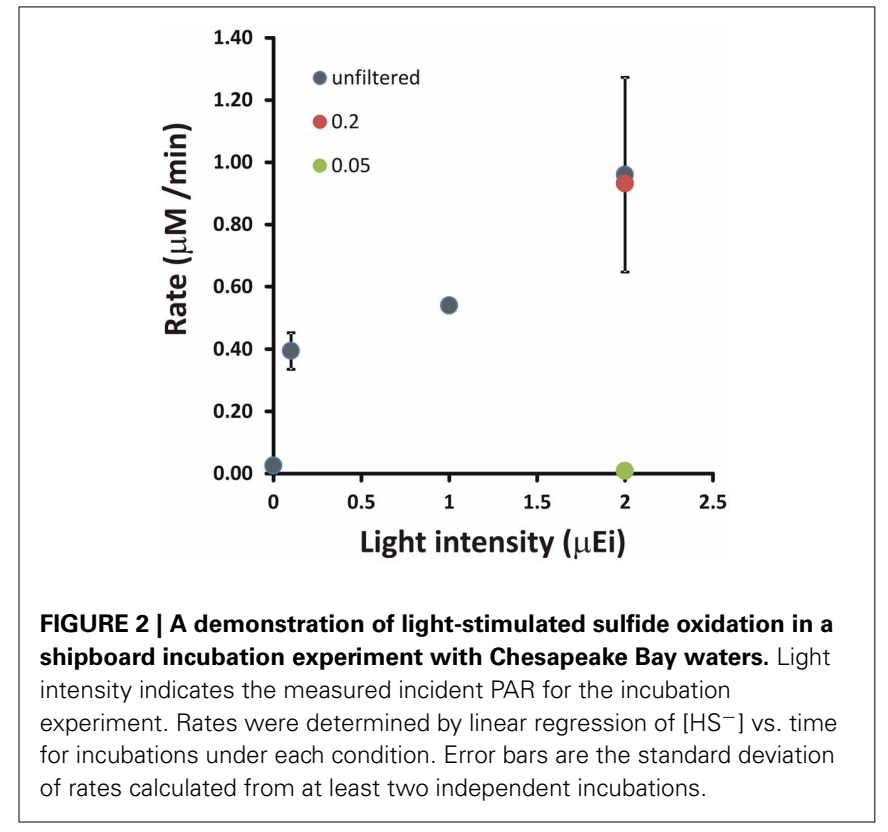

column displayed sulfide consumption under anaerobic conditions (Luther et al., 1988). The key points of this initial observation were that this sulfide oxidation activity passed a $0.22 \mu \mathrm{m}$ filter, was inhibited by treatment with formaldehyde or darkened conditions. In summer 2012, this result was essentially duplicated (Figure 2). Three specific points should be noted the 2012 data set. First, this experiment reproduced an essential component of the seminal 1988 observation, not just light-stimulated, but light-dependent anaerobic sulfide uptake. The fact that this can be observed in just two samples separated by 24 years suggests it is a normal component of the Chesapeake Bay sulfur cycle. Second, the light fluxes required to stimulate sulfide uptake activity are extremely low $\left(<1 \mu \mathrm{Ei} \mathrm{m}^{-2} \mathrm{~s}^{-1}\right)$. If a phototrophic microbe is mediating this reaction, then it must be extremely low light adapted. For comparison, PAR flux on a clear summer day

\section{KEY CONCEPT 4 | PAR}

Photosynthetically active radiation.

at noon at sea level is $\sim 2000-2500 \mu \mathrm{Ei} \mathrm{m}^{-2} \mathrm{~s}^{-1}$. Light intensities in the hypoxic to anoxic layers of the Chesapeake Bay are $<1$ to

\section{KEY CONCEPT 5 | Hypoxic}

Having low dissolved $\mathrm{O}_{2}$ concentrations, typically $<25 \%$ of saturation $(<50-$ $60 \mu \mathrm{M})$, but not lacking dissolved $\mathrm{O}_{2}$ (anoxic).

$\sim 10 \mu \mathrm{Ei} \mathrm{m}^{-2} \mathrm{~s}^{-1}$ due to depth and absorption by phytoplankton and other materials that scatter and absorb light in the photic zone. Finally, this putative microbe must also have a small cell size as the activity is essentially unchanged by $0.22 \mu \mathrm{m}$ filtration. This small cell size and low light intensity suggest that relatively large celled cyanobacteria and algae are not likely to be sulfide oxidizers in this system. Taken together, these latter two points argue in favor of green sulfur bacteria (Chlorobi) as microbes responsible for this activity. 
While the $<0.22 \mu \mathrm{m}$ cell size is generally smaller than Chlorobi observed in laboratory cultures, Chlorobi are generally smaller in size than other cultured bacteria. For example Chlorobaculum tepidum cells are typically squat rods $0.2-0.6 \mu \mathrm{m}$ wide by $0.4-$ $1.0 \mu \mathrm{m}$ long with a corresponding biovolume of $0.01-0.23 \mu \mathrm{m}^{3}$ when grown in the Hanson laboratory (Hiras and Hanson, unpublished data). In comparison, cultured picocyanobacteria biovolumes range from 0.8 to $2.5 \mu \mathrm{m}^{3}$ made up of cells with dimensions $1.0 \mu \mathrm{m} \times 1.3 \mu \mathrm{m}$ to $1.1 \mu \mathrm{m} \times 2.9 \mu \mathrm{m}$ (e.g., Haverkamp et al., 2009). Average marine bacterial cells were found to have $\sim 0.10 \mu \mathrm{m}^{3}$ biovolume (range $-0.04-0.16 \mu \mathrm{m} 3$, Straza et al., 2009) which corresponds to a rod shaped cell of $0.40 \mu \mathrm{m} \times 0.93 \mu \mathrm{m}$ (calculated from formulas in Sun and Liu, 2003). Cells in the environment are generally smaller than cells in cultures (references in Straza et al., 2009). Since large cultured C. tepidum cells are similar in size to average marine bacterial cells, we expect that environmental Chlorobi will be smaller than average marine bacteria, and therefore a significant fraction should pass a $0.22 \mu \mathrm{m}$ filter. In contrast, we expect picocyanobacteria to be average bacterial cell size or somewhat larger and therefore be largely removed by $0.22 \mu \mathrm{m}$ filtration. Picoeukaryotic algae will be even larger.

As a group, the Chlorobi have historically been considered to be strictly anaerobic phototrophs that are confined euxinic environments that receive sunlight (Overmann and Garcia-Pichel, 2006; Imhoff and Thiel, 2010). Molecular sequence data and new isolates have now begun to challenge this view. In the marine environment, rRNA sequences related to Chlorobium (SAR406) have been reported from fully oxic water column samples at the base of the photic zone (Gordon and Giovannoni, 1996). SAR406-related sequences were abundant in anoxic Chesapeake Bay waters (Crump et al., 2007) and in the anoxic zone of Saanich Inlet (Zaikova et al., 2010), a seasonally stratified fjord in British Columbia. More recently, a strain of Chlorobium was isolated from a deep sea hydrothermal vent site (Beatty et al., 2005), where it was proposed that this strain utilizes near IR radiation emanating from hydrothermally heated minerals as a light source. This particular strain was shown to maintain full viability over 2 weeks under fully aerobic conditions in the dark and the absence of sulfide. Finally, a distinct family-level lineage of the Chlorobi containing a putative aerobe has been proposed on the basis of an assembled genome for "Candidatus Thermochlorobacter aerophilum," which occurs in aerobic phototrophic mats of alkaline siliceous hot springs in Yellowstone National Park (Liu et al., 2012). These results suggest that Chlorobi may be able to persist between periods of anoxia or re-colonize temporally unstable anoxic regions by transport from distant anoxic environments or underlying sediments. Furthermore, extant and active populations of Chlorobi are found in the Black Sea chemocline (Manske et al., 2005; Marschall et al., 2010), in permanently stratified marine fjords (Schmidtova et al., 2009), and in meromictic lakes considered to be ancient ocean analogs (Crowe et al., 2008; Lauro et al., 2011). Finally, biomarker evidence indicates that Chlorobi may have been important components of the marine microbial community in sulfidic ancient oceans (Brocks et al., 2005). These collected observations indicate that the Chlorobi or other phototrophic sulfide oxidizers should play an important and previously unrecognized role in sulfide dynamics in the Chesapeake Bay.

\section{WHY PHOTOTROPHIC SULFIDE OXIDIZERS SHOULD MATTER}

The redox potential of the sulfide in most environments is $\sim-270 \mathrm{mV}$ relative to the standard hydrogen electrode. From a microbial perspective, this means that there is substantial free energy available if the oxidation of sulfide is coupled to strong oxidants like $\mathrm{O}_{2}, \mathrm{NO}_{3}^{-}, \mathrm{Fe}^{3+}$ or $\mathrm{Mn}^{3+/ 4+}$. However, in anoxic or suboxic marine pelagic environments, $\mathrm{O}_{2}$ is limited by definition, there is likely to be severe competition for $\mathrm{NO}_{3}^{-}$between phytoplankton and bacterioplankton as an $\mathrm{N}$-source for growth that will maintain it at low levels and oxidized metals are unlikely to be found in significant amounts in the water column. The latter may not be strictly true, however, as prior measurements documented micromolar concentrations of $\mathrm{Mn}^{3+}$ in suboxic Cheseapeake Bay waters (Trouwborst et al., 2006). However, this condition seems to occur primarily when sulfide levels are low. Even so, the ability of chemolithotrophic bacteria to oxidize sulfide will be dependent on the availability of a suitable external electron acceptor.

Phototrophic sulfide oxidizers, through the action of photochemical reaction centers, have the ability to alter the redox potential of electrons using captured light energy, thereby altering the suite of available electron acceptors. In the case of the Chlorobi, reduced ferredoxin is the product of the reaction center. This is significant because the redox potential of Fd is sufficient $(\sim-500 \mathrm{mV})$ to reduce $\mathrm{CO}_{2}$. Indeed, all anaerobic Chlorobi are all thought to utilize the $\mathrm{Fd}$-dependent reductive tricarboxylic acid cycle for $\mathrm{CO}_{2}$ fixation into biomass. In the case of sulfide oxidizing Proteobacteria, the situation is more complicated. The product of the reaction center is a reduced quinone at a redox potential of $\sim-100 \mathrm{mV}$. This is insufficient to directly reduce $\mathrm{CO}_{2}$. However, through a process called reversed electron transport, these electrons can be donated to $\mathrm{NADP}^{+}$generating reductant for the Calvin-Benson-Bassham pathway of autotrophic $\mathrm{CO}_{2}$ fixation, which is utilized by sulfide oxidizing phototrophic Proteobacteria. Chemolithotrophic Proteobacteria are also able to perform reverse electron transport, but without the additional energy input from light energy. Thus, phototrophic sulfide oxidizing Proteobacteria would be expected to out-compete chemolithotrophic sulfide oxidizers if light energy is available. What is currently unclear is if phototrophic Proteobacteria are able to capture the low light levels $\left(<1 \mu \mathrm{Ei} \mathrm{m}^{-2} \mathrm{~s}^{-1}\right)$ that stimulated sulfide oxidation in Chesapeake Bay samples (Figure 2). At this point, what we can say is that culturing efforts carried out in 2011-2013 only yielded Chlorobi in enrichments for phototrophic sulfide oxidizers from Chesapeake Bay water column samples (Findlay et al., unpublished data).

\section{TECHNIQUES FOR MEASURING SULFIDE OXIDATION RATES}

To fully understand the potential role of phototrophic sulfide oxidizers in the Chesapeake Bay and elsewhere, the kinetics of light-dependent sulfide oxidation must be determined (Figure 2), both in environmental samples and laboratory cultures. This necessarily requires the accurate measurement of sulfide concentrations over time courses in samples. The bisulfide anion $\left(\mathrm{HS}^{-}\right)$ is the predominant form of dissolved sulfide at neutral to mildly 
alkaline conditions $\left(\mathrm{H}_{2} \mathrm{~S}<->\mathrm{HS}^{-}+\mathrm{H}^{+}\right.$, pKa $\left.\sim 6.5\right)$ in most marine environments. A broadly applicable method for kinetic analysis of sulfide oxidation in both aerobic and anaerobic microbial systems should provide real-time or near real-time data and have high sensitivity. A further consideration is whether a technique is able to detect more than one sulfur species including the sulfide oxidation products polysulfides and thiosulfate. The ability to measure these oxidized sulfur species enables direct detection of precursor-product relationships and allows one to distinguish between oxidation and cellular uptake.

The bisulfide anion in solution can be measured directly by its UV absorbance $\sim 231 \mathrm{~nm}$ and it can be measured in natural waters even in the presence of dissolved organic materials by spectral deconvolution (Guenther et al., 2001; Luther et al., 2011). However, the presence of microbial cells in kinetic oxidation assays limits the effectiveness of this method due to a high degree of UV absorption and light scattering. The classic method for determining dissolved bisulfide is the Cline or methylene blue assay (Cline, 1969) that relies on the conversion of a colorless precursor to methylene blue in the presence of sulfide. This assay is reliable and has been used extensively in natural systems (e.g., Zopfi et al., 2001) and with phototrophic sulfide oxidizers (e.g., Arieli et al., 1991). However, the Cline assay can be cumbersome for kinetic experiments because rapid sacrificial subsampling of an assay mixture is required. This subsampling in turn changes assay volume which can cause changes in culture illumination for phototrophic microbes. It is also sensitive to interference by polysulfide, the first oxidation product of sulfide, leading to an underestimation of sulfide concentrations (Luther et al., 1985). More recently bimane derivatization has been applied to measure sulfide and other thiols in natural samples (thiol = R-HS-, Rethmeier et al., 1997). While bimane is more sensitive than the Cline assay and also detects sulfite, polysulfides, and thiosulfate, it again requires sacrificial sampling and sample processing. Therefore, it does not provide a real-time read-out of activity. Bimane methods also require significant instrumentation (a gradient capable HPLC with fluorescence detector) to be implemented. For real-time data, respirometric methods (i.e., quantifying sulfide-dependent $\mathrm{O}_{2}$ uptake, Gonzalez-Sanchez et al., 2009) can be utilized for aerobic sulfide oxidizers, but not for anaerobes.

Based on the above considerations, electrochemical methods of sulfide detection fulfill most of these requirements and have been applied both in situ for environmental/water column analysis and in the laboratory to measure sulfide oxidation kinetics in samples and cultures. These methods are particularly appropriate when many short-duration (i.e., minutes to hours) assays need to be performed with high data collection (i.e., several times per minute or more) rates are required to capture initial rates of sulfide oxidation. General reviews on the use of electrodes and electrochemical techniques in microbial ecology and as in situ sensors have been published elsewhere (Revsbech, 2005; Moore et al., 2009). To build upon the observations described above and in our previous Frontiers manuscript (Luther et al., 2011) required that a common set of protocols be developed so that comparable data sets for phototrophic sulfide oxidation kinetic measurements could be collected in several physically distinct laboratory settings by different personnel. Here, we describe the basic apparatus and document the variability in these measurements so that other groups wishing to utilize these methods may do so more readily. In doing so, our goal is to provide a solid technical foundation for others that wish to make similar measurements and allow them to benefit from our experiences in setting up these types of experimental rigs.

\section{ELECTROCHEMICAL MEASUREMENT OF PHOTOTROPHIC SULFIDE UPTAKE}

The apparatus for measuring phototrophic sulfide oxidation by electrochemical methods is relatively straightforward: an electrochemical analyzer system equipped with gold- amalgam $(\mathrm{Au} / \mathrm{Hg})$ electrodes, a clear temperature controlled electrochemical cell that can be made anoxic, a light meter equipped with a quantum PAR sensor, a controlled illumination source and a shroud to exclude extraneous light. The details of electrode fabrication have been presented in detail elsewhere (Brendel and Luther, 1995; Luther et al., 2008) and will not be described here.

The schematic for arranging these components is shown in as general a fashion as possible (Figure 3). The specific brand/manufacturer of the components should not, in principle, affect the outcome of the experiment. The electrochemical cell, light source, and light sensor are contained inside the shroud with cables, gas and water (for temperature control) lines traversing the shroud. The electrochemical analyzer, control and data capture computer, light meter, temperature control (recirculating heater/chiller) and gas source are all located outside of the shroud. In principle, the shroud can be any light blocking fabric or non-reflective material (i.e., velvet, cardboard, etc.). For ease of manipulation, a frame constructed of stock laboratory stands and crossbars can be draped with multiple layers of black plastic sheeting (available at local hardware or paint stores) secured to the frame by binder clips. The flexibility of the plastic allows it to be overlapped and taped where cables and lines penetrate the shroud to minimize light leakage. A variac (voltage attentuator) connected to a single bulb fixture provides variable light intensity. Full spectrum incandescent bulbs (i.e., G.E. Reveal) ranging from 10 to $60 \mathrm{~W}$ output provide a broad range for low and high light intensity experiments. Using this apparatus, we can routinely obtain a steady light field of $0.1 \mu$ Ei PAR $(\sim 0.005 \%$ of summer noontime light intensity). For most purposes this will be low enough light intensity. However, for extremely low light intensity, i.e., for replicating light levels at the upper reaches of the Black Sea euxinic zone (0.0008-0.0022 $\mu \mathrm{Ei}$, Manske et al., 2005), utilizing this apparatus in a darkened room and with higher sensitivity light meters/sensors may be necessary.

The electrochemical cell is attached to an Ar supply so that $\mathrm{O}_{2}$ can be excluded during measurements. Ar is preferable to $\mathrm{N}_{2}$ due to its higher density giving it the ability to "cap" the solution in the electrochemical cell. For work with pure cultures, collecting cells for assay under anoxic conditions is also important as is the buffer used for maintaining $\mathrm{pH}$ during the assay. After experimenting with various buffering systems, we have found that anoxic 0.1 M HEPES at $\mathrm{pH} 7.4$ provides effective $\mathrm{pH}$ control without introducing any background signals during cyclic voltammetry. Cells are typically washed twice by centrifugation (with all transfers to centrifuge bottles carried 


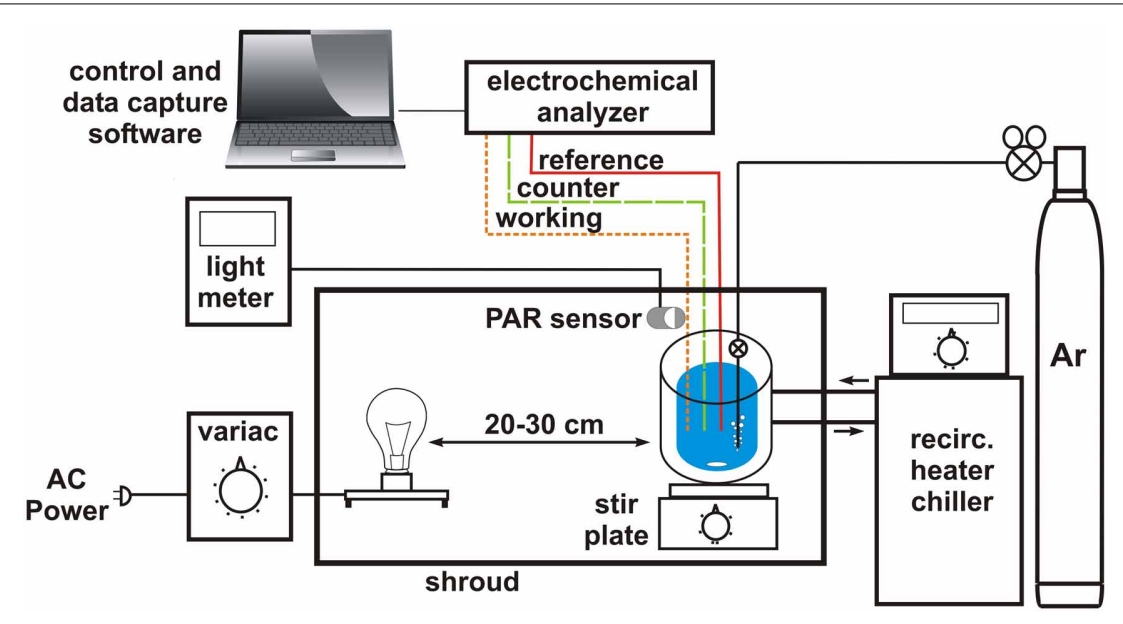

FIGURE 3 | Schematic of experimental apparatus for reproducibly measuring phototrophic sulfide uptake. Details for particular components are provided in the text. "Reference," "counter," and "working" refer to the electrodes of the electrochemical analyzer system.

out in an anaerobic chamber or glove bag) and resuspended in HEPES buffer to remove any medium components and external substrate.

For any given measurement, the empty electrochemical cell is first flushed with Ar, followed by the addition of anoxic HEPES buffer or environmental sample and a short period to allow for equilibration to temperature (i.e., for the moderate thermophile C. tepidum). At this point scans are performed to verify that the cell is anoxic (i.e., no observable $\mathrm{O}_{2}$ and $\mathrm{H}_{2} \mathrm{O}_{2}$ peaks in the voltammogram). If necessary, the solution is purged with Ar until no $\mathrm{O}_{2}$ is detectable. This is followed by the addition of washed cell suspension. The assay is then initiated by the addition of sulfide to a defined concentration. Typical working volume for an assay is $\sim 20 \mathrm{ml}$ in the electrochemical cells employed in our laboratories. The suspension in the electrochemical cell is continually stirred except when cyclic voltammograms are being collected ( every 15-60 s). A critical control is to measure the sulfide loss rate from cell-free buffer to determine if there is a significant abiotic loss component in the apparatus. One potential cause is poor sealing of the electrochemical cell that allows volatile sulfide to escape. This loss rate should be $<1 \%$ of the rate observed in the presence of cells. To compare between samples, the initial rate of sulfide loss is determined by linear regression of the sulfide concentration values. In the case of cultures, this rate is then normalized for the amount of biomass to provide a biochemical specific activity, i.e., the rate of sulfide oxidation catalyzed by each unit of biomass in the assay. To collect kinetic data and compare cells under different environmental parameters (i.e., varying light intensity or $\mathrm{HS}^{-}$ concentration), it is important to maintain biomass at as constant a level as possible between assays near the top of the linear range of activity vs. biomass (i.e., see Figure 6 in Luther et al., 2011) so that small fluctuations in sulfide uptake rate can be sensitively and reproducibly detected.

When the procedures outlined above are taken, directly comparable results that display no significant statistical difference can be produced by different personnel in different laboratories (Figure 4). Note that this does not mean the data produced are

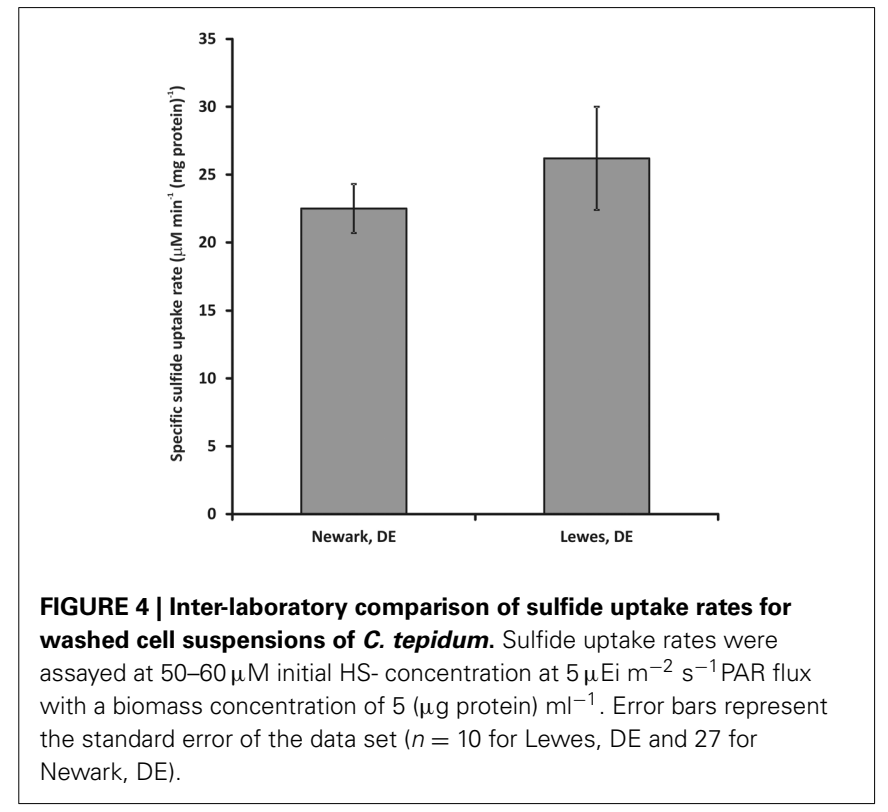

identical, as can be seen from the magnitude of the error bars in the inter-laboratory comparison. This noise in the data set may derive from subtle differences in strain growth conditions between the two laboratories or experimental apparatus. For example, the Lewes laboratory typically employs an automated cell holder while the Newark laboratory uses manual control of cell stirring. However, the magnitude of the variance is similar between the two laboratories suggesting that the equipment differences do not impart significantly greater variance in one laboratory vs. the other.

A final caveat is that the apparatus here and its use as described measures the disappearance of sulfide from solution, which is distinct from sulfide oxidation and could also be due to passive loss due to volatilization (e.g., DeLeon et al., 2012). Assuming that control measurements document that passive loss is not 
occurring, the absence of additional evidence for the production of intermediate oxidation state sulfur species (i.e., polysulfide, $\mathrm{S}(0)$, thiosulfate, etc.), requires that the biologically driven sulfide loss be interpreted as sulfide uptake. As noted above, the ability to readily detect polysulfide and thiosulfate using the electrode systems outlined here allows for the possibility of discriminating uptake from oxidation and establishing precursorproduct relationships. Other electrodes, for example $\mathrm{Ag} / \mathrm{Ag}_{2} \mathrm{~S}$ electrodes for total $S^{2-}$ activity (e.g., described in Revsbech et al., 1983 and Revsbech, 1989) that can provide good sulfide sensitivity are limited in this aspect and can be subject to other interferences as discussed elsewhere (e.g., Kühl et al., 1998). The alternative amperometric electrode system described by Kühl et al. (1998), similarly is unable to provide information on more oxidized sulfur species and therefore unable to distinguish directly between oxidation and passive loss or uptake.

\section{CONCLUDING REMARKS}

This focused review has tried to convey the current understanding of sulfidic marine systems as ancient ocean analogs. In these environments, phototrophic sulfide oxidizers should have thrived, including members of the Chlorobi. Furthermore, current and past data from the Chesapeake Bay indicate that Chlorobi may have more significant roles to play in modern, transiently anoxic marine ecosystems than is currently appreciated, though there are still many experiments that need to be performed to rigorously test this hypothesis. To facilitate these experiments, we have outlined techniques to measure phototrophic sulfide consumption rates at low light intensities with both cultures and environmental samples.

\section{ACKNOWLEDGMENTS}

This project was supported by NSF grant MCB-0919682 to Thomas E. Hanson and George W. Luther III and OCE-1155385 to George W. Luther III.

\section{REFERENCES}

Arieli, B., Padan, E., and Shahak, Y. (1991). Sulfide-induced sulfide-quinone reductase activity in thylakoids of Oscillatoria limnetica. J. Biol. Chem. 266, $104-111$.

Beatty, J. T., Overmann, J., Lince, M. T., Manske, A. K., Lang, A. S., Blankenship, R. E., et al. (2005). An obligately photosynthetic bacterial anaerobe from a deep-sea hydrothermal vent. Proc. Natl. Acad. Sci. U. S. A. 102, 9306-9310. doi: 10.1073/pnas.0503674102

Boicourt, W. G. (1992). "Influences of circulation processes on dissolved oxygen in Chesapeake Bay," in Oxygen Dynamics in the Chesapeake Bay: A Synthesis of Recent Research, Maryland and Virginia Sea Grant Colleges, Publication Nos. UM-SG-TS-92-01 and VSG-92-01, eds D. E. Smith, M. Leffler, and G. Mackiernan (College Park, MD), 7-59.

Breitburg, D. L. (1990). Nearshore hypoxia in the Chesapeake Bay: patterns and relationships among physical factors. Estuar. Coast. Shelf Sci. 30, 593-609. doi: 10.1016/0272-7714(90)90095-9

Brendel, P. J., and Luther, III. G. W. (1995). Development of a gold amalgam voltammetric microelectrode for the determination of dissolved $\mathrm{Fe}, \mathrm{Mn}, \mathrm{O} 2$, and S(-II) in porewaters of marine and freshwater sediments. Environ. Sci. Technol. 29, 751-761. doi: 10.1021/es00003a024

Brocks, J. J., Love, G. D., Summons, R. E., Knoll, A. H., Logan, G. A., and Bowden, S. A. (2005). Biomarker evidence for green and purple sulphur bacteria in a stratified palaeoproterozoic sea. Nature 437, 866-870. doi: 10.1038/nature04068
Canfield, D. E., Habicht, K. S., Thamdrup, B. (2000). The Archean sulfur cycle and the early history of atmospheric oxygen. Science 288, 658-661. doi: 10.1126/science.288.5466.658

Cline, J. D. (1969). Spectrophotometric determination of hydrogen sulfide in natural waters. Limnol. Oceanogr. 14, 454-458. doi: 10.4319/lo.1969.14.3.0454

Crowe, S. A., Jones, C., Katsev, S., Magen, C., O’Neill, A. H., Sturm, A., et al. (2008). Photoferrotrophs thrive in an archean ocean analogue. Proc. Natl. Acad. Sci. U.S.A. 105, 15938-15943. doi: 10.1073/pnas.0805313105

Crump, B. C., Peranteau, C., Beckingham, B., and Cornwell, J. C. (2007). Respiratory succession and community succession of bacterioplankton in seasonally anoxic estuarine waters. Appl. Environ. Microbiol. 73, 6802-6810. doi: 10.1128/AEM.00648-07

DeLeon, E. R., Gilbrian, F. S., and Olson, K. R. (2012). Passive loss of hydrogen sulfide in biological experiments. Anal. Biochem. 421, 203-207. doi: 10.1016/j.ab.2011.10.016

Farquhar, J., Zerkle, A. L., and Bekker, A. (2011). Geological constraints on the origin of oxygenic photosynthesis. Photosyn. Res. 107, 11-36. doi: 10.1007/s11120010-9594-0

Frei, R., Gaucher, C., Poulton, S. W., and Canfield, D. E. (2009). Fluctuations in precambrian atmospheric oxygenation recorded by chromium isotopes. Nature 461, 250-253. doi: 10.1038/nature08266

Gill, B. C., Lyons, T. W., Young, S. A., Kump, L. R., Knoll, A. H., and Saltzman, M. R. (2011). Geochemical evidence for widespread euxinia in the later Cambrian ocean. Nature 469, 80-83. doi: 10.1038/nature09700

Gonzalez, B. C., Iliffe, T. M., Macalady, J. L., Schaperdoth, I., and Kakuk, B. (2012). Microbial hotspots in anchialine blue holes: initial discoveries from the Bahamas. Hydrobiologia 677, 149-156. doi: 10.1007/s10750-011-0932-9

Gonzalez-Sanchez, A., Tomas, M., Dorado, A. D., Gamisans, X., Guisasola, A., Lafuente, J., et al. (2009). Development of a kinetic model for elemental sulfur and sulfate formation from the autotrophic sulfide oxidation using respirometric techniques. Water Sci. Technol. 59, 1323-1329. doi: 10.2166/wst.2009.110

Gordon, D. A., and Giovannoni, S. J. (1996). Detection of stratified microbial populations related to Chlorobium and Fibrobacter species in the Atlantic and Pacific oceans. Appl. Environ. Microbiol. 62, 1171-1177.

Guenther, E. A., Johnson, K. S., and Coale, K. H. (2001). Direct ultraviolet spectrophotometric determination of total sulfide and iodide in natural waters. Anal. Chem. 73, 3481-3487. doi: 10.1021/ac0013812

Hagy, J. D., Boynton, W. R., Keefe, C. W., and Wood, K. V. (2004). Hypoxia in Chesapeake Bay, 1950-2001: long-term change in relation to nutrient loading and river flow. Estuaries 27, 634-658. doi: 10.1007/BF02907650

Harding, L. W. Jr., Leffler, M., and Mackiernan, G. E. (1992). Dissolved oxygen in the Chesapeake Bay: A Scientific Consensus. Maryland Seagrant College Publication No. UM-SG-TS-92-03. College Park, MD: Maryland Sea Grant.

Haverkamp, T. H., Schouten, D., Doeleman, M., Wollenzien, U., Huisman, J., and Stal, L. J. (2009). Colorful microdiversity of Synechococcus strains (picocyanobacteria) isolated from the Baltic Sea. ISME J. 3, 397-408. doi: 10.1038/ismej.2008.118

Imhoff, J. F., and Thiel, V. (2010). Phylogeny and taxonomy of chlorobiaceae. Photosyn. Res. 104, 123-36. doi: 10.1007/s11120-009-9510-7

Itsweire, E. C., and Phillips, O. M. (1987). "Physical processes that control circulation and mixing in estuarine systems," in Perspectives on the Chesapeake Bay: Recent Advances in Estuarine Sciences, Chesapeake Research Consortium, Gloucester Point, Virginia, Publication No. 127. eds M. P. Lynch and E. C. Krome, (Gloucester Point, VA: Chesapeake Research Consortium), 57-53.

Jonas, R. B. (1992). "Microbial processes, organic matter and oxygen demand in the water column," in Oxygen Dynamics in the Chesapeake Bay: A Synthesis of Recent Research, Maryland and Virginia Sea Grant Colleges, Publication Nos. UM-SGTS-92-01 and VSG-92-01, eds D. E. Smith, M. Leffler, and G. Mackiernan (College Park, MD: Maryland Sea Grant and Virginia Sea Grant), 113-148.

Jonas, R. B. (1997). Bacteria, dissolved organics and oxygen consumption in salinity stratified Chesapeake Bay, an anoxia paradigm. Am. Zool. 37, 612-620.

Jonas, R. B., and Tuttle, J. H. (1990). Bacterioplankton and organic carbon dynamics in the lower mesohaline Chesapeake Bay. Appl. Environ. Microbiol. 56, 747-757.

Kemp, W. M., Sampou, P. A., Garber, J., Tuttle, J., and Boynton, W. R. (1992). Seasonal depletion of oxygen from bottom waters of Chesapeake Bay: role of benthic and planktonic respiration and physical exchange processes. Mar. Ecol. Prog. Ser. 85, 137-152. doi: 10.3354/meps085137 
Kühl, M., Steuckart, C., Eickert, G., and Jeroschewski, P. (1998). A H 2 S microsensor for profiling biofilms and sediments. Aquat. Microbial. Ecol. 15, 201-209. doi: 10.3354/ame015201

Lauro, F. M., DeMaere, M. Z., Yau, S., Brown, M. V., Ng, C., Wilkins, D., et al. (2011). An integrative study of a meromictic lake ecosystem in antarctica. ISME J. 5, 879-895. doi: 10.1038/ismej.2010.185

Lewis, B. L., Glazer, B. T., Montbriand, P. J., Luther, III. G. W., Nuzzio, D. B., Deering, T., et al. (2007). Short-term and interannual variability of redox-sensitive chemical parameters in hypoxic/anoxic bottom waters of the Chesapeake Bay. Mar. Chem. 105, 296-308. doi: 10.1016/j.marchem.2007. 03.001

Liu, Z., Klatt, C. G., Ludwig, M., Rusch, D. B., Jensen, S. I., Kühl, M., et al. (2012). "Candidatus Thermochlorobacter aerophilum:" an aerobic chlorophotoheterotrophic member of the phylum Chlorobi defined by metagenomics and metatranscriptomics. ISME J. 6, 1869-1882. doi: 10.1038/ismej.2012.24

Luther, III. G. W., Ferdelman, T., and Tsamakis, E. (1988). Evidence suggesting anaerobic oxidation of the bisulfide ion in Chesapeake Bay. Estuaries 11, 281-285. doi: 10.2307/1352015

Luther, III. G. W., Giblin, A. E., and Varsolona, D. R. (1985). Polarographic analysis of sulfur species in marine pore waters. Limnol. Oceanogr. 30, 727-736. doi: 10.4319/lo.1985.30.4.0727

Luther, III. G. W., Findlay, A. J., Macdonald, D. J., Owings, S. M., Hanson, T. E., Beinart, R. A., et al. (2011). Thermodynamics and kinetics of sulfide oxidation by oxygen: a look at inorganically controlled reactions and biologically mediated processes in the environment. Front. Microbiol. 2:62. doi: 10.3389/fmicb.2011.00062

Luther, III. G. W., Glazer, B. T., Ma, S., Trouwborst, R. E., Moore, T. S., Metzger, E., et al. (2008). Use of voltammetric solid-state (micro)electrodes for studying biogeochemical processes: laboratory measurements to real time measurements with an in situ electrochemical analyzer (ISEA). Mar. Chem. 108, 221-235. doi: 10.1016/j.marchem.2007.03.002

Luther, III. G. W., Ma, S. Trouwborst, R. Glazer, B. Blickley, M. Scarborough, R., W. et al. (2004). The roles of anoxia, $\mathrm{H}_{2} \mathrm{~S}$, and storm events in fish kills of dead-end canals of Delaware Inland Bays. Estuaries 27, 551-560. doi: 10.1007/BF02803546

Macalady, J. L., Schaperdoth, I., Fulton, J. M., Freeman, K. H., and Hanson, T. E. (2010). Microbial biogeochemistry of a meromictic blue hole. Geochim. Cosmochim. Acta 74, A651-A651.

Malone, T. C. (1991). "River flow, phytoplankton production and oxygen depletion in Chesapeake Bay," in Modern and Ancient Continental Shelf Anoxia, Geological Society Special Publication No. 58, eds R. V. Tyson and T. H. Pearson, (London: Geological Society), 83-92. doi: 10.1144/GSL.SP.1991.058.01.06

Malone, T. C., Crocker, L. H., Pike, S. E., and Wendler, B. W. (1988). Influence of river flow on the dynamics of phytoplankton production in a partially stratified estuary. Mar. Ecol. Prog. Ser. 48, 235-249. doi: 10.3354/meps048235

Manske, A. K., Glaeser, J., Kuypers, M. M., and Overmann, J. (2005). Physiology and phylogeny of green sulfur bacteria forming a monospecific phototrophic assemblage at a depth of 100 meters in the Black Sea. Appl. Environ. Microbiol. 71, 8049-8060. doi: 10.1128/AEM.71.12.8049-8060.2005

Marschall, E., Jogler, M., Hessge, U., and Overmann, J. (2010). Large-scale distribution and activity patterns of an extremely low-light-adapted population of green sulfur bacteria in the Black Sea. Environ. Microbiol. 12, 1348-1362. doi: 10.1111/j.1462-2920.2010.02178.x

Moore, T. S., Mullaugh, K. M., Holyoke, R. R., Madison, A. S., Yucel, M., and Luther, III. G. W. (2009). Marine chemical technology and sensors for marine waters: potentials and limits. Ann. Rev. Mar. Sci. 1, 91-115. doi: 10.1146/ annurev.marine.010908.163817

Officer, C. G., Biggs, R. B., Taft, J. L., Cronin, L. E., Tyler, M. A., and Boynton, W. R. (1984). Chesapeake Bay anoxia: Origin, development and significance. Science 23, 22-27. doi: 10.1126/science.223.4631.22

Overmann, J., and Garcia-Pichel, F. (2006). "The phototrophic way of life," in The Prokaryotes, 3rd Edn, eds M. Dworkin, S. Falkow, E. Rosenberg, K.-H. Schleifer, and E. Stackebrandt (New York, NY: Springer), 203-257.

Poulton, S. W., Fralick, P. W., and Canfield, D. E. (2004). The transition to a sulphidic ocean approximately 1.84 billion years ago. Nature 431, 173-177. doi: 10.1038 /nature02912

Rethmeier, J., Rabenstein, A., Langer, M., and Fischer, U. (1997). Detection of traces of oxidized and reduced sulfur compounds in small samples by combination of different high-performance liquid chromatography methods. J. Chromatogr. A 760, 295-302. doi: 10.1016/S0021-9673(96)00809-6
Revsbech, N. P. (1989). An oxygen microelectrode with a guard cathode. Limnol. Oceanogr. 34, 474-478. doi: 10.4319/lo.1989.34.2.0474

Revsbech, N. P. (2005). Analysis of microbial communities with electrochemical microsensors and microscale biosensors. Meth. Enzymol. 397, 147-166. doi: 10.1016/S0076-6879(05)97009-2

Revsbech, N. P., Jørgensen, B. B., Blackburn, T. H., and Cohen, Y. (1983). Microelectrode studies of the photosynthesis and $\mathrm{O} 2, \mathrm{H} 2 \mathrm{~S}$, and $\mathrm{pH}$ profiles of a microbial mat. Limnol. Oceanogr. 28, 1062-1074. doi: 10.4319/lo.1983.28.6.1062

Sanford, L. P., Sellner, K. G., and Breitburg, D. L. (1990). Covariability of dissolved oxygen with physical processes in the summertime Chesapeake Bay. J. Mar. Res. 48, 567-590. doi: 10.1357/002224090784984713

Schmidtova, J., Hallam, S. J., and Baldwin. S. A. (2009). Phylogenetic diversity of transition and anoxic zone bacterial communities within a near-shore anoxic basin: Nitinat lake. Environ. Microbiol. 11, 3233-3251. doi: 10.1111/j.14622920.2009.02044.x

Schubel, J. R., and Pritchard, D. W. (1986). Responses of upper Chesapeake Bay to variations in discharge of the Susquehanna River. Estuaries 9, 236-249. doi: $10.2307 / 1352096$

Scott, C., Lyons, T. W., Bekker, A., Shen, Y., Poulton, S. W., Chu, X., et al. (2008). Tracing the stepwise oxygenation of the proterozoic ocean. Nature 452, 456-459. doi: 10.1038/nature06811

Sleep, N. H., and Bird, D. K. (2008). Evolutionary ecology during the rise of dioxygen in the earth's atmosphere. Philos. Trans. R. Soc. Lond. B Biol. Sci. 363, 2651-2664. doi: 10.1098/rstb.2008.0018

Steadman, D. W., Franz, R., Morgan, G. S., Albury, N. A., Kakuk, B., Broad, K., et al. (2007). Exceptionally well preserved late quaternary plant and vertebrate fossils from a blue hole on Abaco, the Bahamas. Proc. Natl. Acad. Sci. U.S.A. 104, 19897-19902. doi: 10.1073/pnas.0709572104

Straza, T. R., Cottrell, M. T., Ducklow, H. W., and Kirchman, D. L. (2009). Geographic and phylogenetic variation in bacterial biovolume as revealed by protein and nucleic acid staining. Appl. Environ. Microbiol. 75, 4028-4034. doi: 10.1128/AEM.00183-09

Sun, J., and Liu, D. (2003). Geometric models for calculating cell biovolume and surface area for phytoplankton. J. Plankton Res. 25, 1331-1346. doi: 10.1093/plankt/fbg096

Taft, J. L., Taylor, W. R., Hartwig, E. O., and Loftus, R. (1980). Seasonal oxygen depletion in the Chesapeake Bay. Estuaries 3, 242-247. doi: 10.2307/1352079

Trouwborst, R. E., Clement, B. G., Tebo, B. M., Glazer, B. T., and Luther, III. G. W. (2006). Soluble Mn(III) in suboxic zones. Science 313, 1955-1957. doi: 10.1126/science. 1132876

Wille, M., Nägler, T. F., Lehmann, B., Schröder, S., and Kramers, J. D. (2008). Hydrogen sulphide release to surface waters at the Precambrian/Cambrian boundary. Nature 453, 767-769. doi: 10.1038/nature07072

Zaikova, E., Walsh, D. A., Stilwell, C. P., Mohn, W. W., Tortell, P. D., and Hallam, S. J. (2010). Microbial community dynamics in a seasonally anoxic fjord: Saanich inlet, British Columbia. Environ. Microbiol. 12, 172-191. doi: 10.1111/j.14622920.2009.02058.x

Zopfi, J., Ferdelman, T. G., Jørgensen, B. B., Teske, A., and Thamdrup, B. (2001). Influence of water column dynamics on sulfide oxidation and other major biogeochemical processes in the chemocline of Mariager Fjord (Denmark). Mar. Chem. 74, 29-51. doi: 10.1016/S0304-4203(00)00091-8

Conflict of Interest Statement: The authors declare that the research was conducted in the absence of any commercial or financial relationships that could be construed as a potential conflict of interest.

Received: 03 May 2013; accepted: 24 November 2013; published online: 19 December 2013.

Citation: Hanson TE, Luther III GW, Findlay AJ, MacDonald DJ and Hess D (2013) Phototrophic sulfide oxidation: environmental insights and a method for kinetic analysis. Front. Microbiol. 4:382. doi: 10.3389/fmicb.2013.00382

This article was submitted to Microbiology, a section of the journal Frontiers in Microbiology.

Copyright (c) 2013 Hanson, Luther, Findlay, MacDonald and Hess. This is an openaccess article distributed under the terms of the Creative Commons Attribution License (CC BY). The use, distribution or reproduction in other forums is permitted, provided the original author(s) or licensor are credited and that the original publication in this journal is cited, in accordance with accepted academic practice. No use, distribution or reproduction is permitted which does not comply with these terms. 